\title{
PRIMARY RETINAL INFILTRATION OF PALE, PULVERULENT, STELLATE AND PURPURIC CHARACTER AND ACCOMPANYING NEPHRITIS IS A PATHOGNOMIC SIGN OF AZOTEMIC ANAEMIA*
}

\author{
BY
}

HENRI LAGRANGE

PARIS

THE subject of this paper refers neither to phenomena of papillary oedema assignable to the intracranial hypertension accompanying chloraemia, nor to retinal haemorrhages attributable to hypertension. Certain recent publications assign such importance to these conditions that they imply that general hypertension is the fundamentally pathogenic character of albuminuric retinitis. Here, on the other hand, it is desired to call attention to the pathognomonic character of retinal lesions which are connected with azotemia and, in this respect, are included among forms of retinitis present in grave types of anaemia.

\section{I.-The Factor Constituted by Azotemic Retinitis}

On April 22, 1910, F. Widal published, in collaboration with V. Morax and André Weill and under the auspices of the Société Médicale des Hôpitaux de Paris, a memoir dealing with seventeen cases of supposedly albuminuric retinitis. In 11 of these cases, the blood urea exceeded 2 grams, in 4 cases it ranged from 0.96 to 1.67 grams, and in 2 cases it varied from 0.50 to 1 gram. Victor Morax and André Weill, examining the frequency of the occurrence of retinal lesions in cases of azotemia, observed retinal lesions in 52 per cent. of a group of 54 cases of increased blood urea, the azotemia present being constantly grave. RochonDuvigneaud summarizes this discussion as follows ${ }^{1}$.

“ The 54 cases of retinitis discussed by Widal and Weill may be grouped as follows : in 17 cases, the existing retinitis revealed the presence of nephritis, as commonly occurring in cases appearing at ophthalmological services on account of visual disturbances, the patients considering their general health excellent and complaining only of defective vision. In 10 of these 17 cases, the first determination of the blood urea showed a range of 0.57 to 0.96 gram per litre of serum. Azotemia was therefore clearly present, but of low degree. The blood urea increased in all of these cases at a later period, sometimes showing remission. In 1 case, for

1. Rochon-Duvigneaud. Report, French Society of Ophthalmology, 1912.

- Received August 29, 1940. 
example, the blood urea declined from 0.96 to 0.45 gram, then rose to 1.27 grams, reaching the proportion of 2.14 grams four months before death ensued. Seven of the 10 cases were followed up, dying from the fifth to the twenty-second month following the detection of the retinitis.

" Retinitis likewise revealed the presence of nephritis in another group of four cases. Here the blood urea first determined ranged from 1 to 2 grams. Included in this group is the case of a youth of 17, presenting myopia and retinitis, and dying three months after the first examination, with blood urea of 4.38 grams. A man, aged 21 , presented rather recent retinitis, with blood urea already consisting of 2.01 grams. In a man, aged 27 years, the initial blood urea was of 2.23 grams, the patient dying eight months later. The fourth case was ambulant four days before death, with blood urea of 4.38 grams and retinitis which had been noted two months previously.

"Another group included 14 cases in" which nephritis had been recognized for various periods of time, the blood urea remaining normal up to the time of examination. Azotemia was shown by the detection of retinitis.

"A fourth and final group consists of 25 cases of retinitis, occurring in clearly marked azotemia. Such cases are often encountered in medical hospital services where cases of nephritis are systematically examined and diagnosed. Such cases form a certain contrast with cases like those of the first group, consisting of those presenting ocular complications of nephritis and seen by ophthalmologists before the general bodily decline results in resort to general medical treatment."

As confirmed in this way, azotemia has given rise to various studies upon toxic retentions of different types, such as nitrogenous, residual, uric acid, creatinic, creatininic, aminic or indoxylic. These studies have especially tended to overthrow the idea that the renal and retinal changes are produced by a common cause and to show rather that they are not mutually subordinate, but that they are parallel and concomitant, and, as the German writers express it, " co-ordinate."

\section{II.-The Coincidence of Anaemia and Primary, Pale, Pulverulent Infiltration of the Retina}

The major test of insufficiency of the renal functions constituted by azotemia cannot fail to be associated with the grave symptom inherent in retinitis. However, is it well founded to assign to hypertension all the various elements and forms of the retinal lesion observed in chronic nephritis solely because azotemia is a frequent corollary of hypertension and because hypertension is a factor concerned in the production of retinal haemorrhages? 
It is quite impossible to ignore the remarkable coexistence of anaemia and azotemia, the equally remarkable coexistence of anaemia and primary, pale, pulverulent, stellate and purpuric infiltration of the retina, and the identity of this retinal lesion of azotemic anaemia with retinal lesions observed in grave forms of anaemia developing without the occurrence of hypertension.

The somatic symptomatology of the retinitis of pernicious anaemia allies this form of retinitis to leukaemic and albuminuric retinitis in such a degree that the descriptions referring to the three forms are identical in various ophthalmological atlases and as illustrated by plates 21 and 23 in the well-known smaller atlas of Haab. Albuminuric retinitis, like that of pernicious anaemia, produces merely slight amblyopia, but it has the special features of occurring with great constancy, at relatively early periods, and never in association with established hypertension. Haemorrhagic points in the retina form also a part of the ordinary picture of gravid pernicious anaemia, which $\mathrm{Ch}$. Aubertin considers a distinct morbid entity, which develops without hypertension, but with pallor, oedema, anorexia, slight non-azotemic albuminuria and anaemia which is usually plastic.

Retinal haemorrhages occur almost constantly in the Ehrlich type of aplastic anaemia.

A study of retinal lesions occurring in pernicious anaemia and the several types of leukaemia, made by Del Duca ${ }^{1}$, is worthy of note. This writer describes ä blood-vascular syndrome and one dependent upon hypertension of the cerebro-spinal fluid. According to Victor Morax ${ }^{2}$, whitish areas and haemorrhagic points, exactly like those present in albuminuric retinitis, occur in one of every five cases of myeloid leukaemia This identity is morphological, but the functional disturbances present in both conditions are similarly slight or absent.

There are doubtless many differences between the several types of anaemia, especially with reference to the ill-defined haemorrhagic process governing the retinal lesions which we are discussing. Among their analogies, at all events, retinitis is remarkable on account of its frequency and its non-specific character. For illustrative purposes, we may review the anatomico-clinical features of the retinitis accompanying myeloid leukaemia.

1. Anatomically.-Integrity of the retinal vessels contrasts with areas of haematic extravasation in the retinal surface along the sheath of the vessels (Roth), with leucocytic infiltration so marked

1. DEL Duca. A new pathogenic theory referring to papillo retinal lesions occurring in pernicious anaemia and various forms of leukaemia. Revistı OtoNeuro-Oftalmologica e Radio-Neuro-Chirurgica, Vol X, fasc. 4, p. 438, 1933.

2. Victor Morax. Leukaemic retinitis. Précis d'Ophtalmologie, p. 505, 1931. Masson and Cie., publisbers, Paris. 
that Leber has suggested the possibility of diapedesis (?) of the red and white cells. Finally, a fibrinous exudate infiltrates the ganglionic layer (stratum ganglionare), sometimes producing vaulting of the internal limiting membrane (Fleichenfeld) or external limiting membrane toward the choroid (Deutschmann, Murakami). Leber, Poncet, Deutschmann, Fleichenfeld, Bondi and others have proved that the choroid is normal in chronic leukaemia, just as Rochon-Duvigneaud has stressed the normal condition of the choroid tract in albuminuric retinitis.

2. Clinically.-The case reported by Leber, in 1876 , is retrospectively illuminating. In this case, retinal lesions occurred in coexistent leukaemia and albuminuria. There is thus difficulty, considered unsurmountable at the time of this report, in selecting the real cause of the lesions, which may seemingly be due to either of the two conditions mentioned.

This brief anatomico-clinical review suffices to explain a parallel more fully developed in the subjoined differential table.

\begin{tabular}{l|c|l}
\hline $\begin{array}{c}\text { Primary, Pale, Pulverulent } \\
\text { Infiltration present in } \\
\text { albuminuric retinitis }\end{array}$ & $\begin{array}{c}\text { Retinitis in malignant } \\
\text { types of anaemia }\end{array}$ & \multicolumn{1}{|c}{$\begin{array}{c}\text { Retinal lesions in } \\
\text { hypertension }\end{array}$} \\
\hline $\begin{array}{l}\text { Primary white, pulveru- } \\
\text { lent patches. Small pur- } \\
\text { puric haemorrbages in } \\
\text { the peri-arterial sheaths }\end{array}$ & Idem. & $\begin{array}{l}\text { Coagulative areas of red } \\
\text { blood. Arterial oblitera- } \\
\text { tions and ruptures, with } \\
\text { secondary white or cot- } \\
\text { tony patches }\end{array}$ \\
$\begin{array}{l}\text { Visual disturbances, } \\
\text { slight or absent - }\end{array}$ & Idem. & $\begin{array}{l}\text { Immediate visual dis- } \\
\text { turbances, of diagnostic } \\
\text { import (amaurosis, posi- } \\
\text { tive scotomata) }\end{array}$ \\
$\begin{array}{l}\text { Anaemia constantly } \\
\text { present }-\end{array}$ & Idem. & $\begin{array}{l}\text { Anaemia variably } \\
\text { Hypertension frequent- } \\
\text { ly present - }\end{array}$ \\
$\begin{array}{l}\text { Azotemia, high or in- } \\
\text { creasing - }\end{array}$ & $\begin{array}{l}\text { Hypertension absent } \\
\text { Hypotension usual }\end{array}$ & $\begin{array}{l}\text { Hypertension constant } \\
\text { and considerable }\end{array}$ \\
\hline
\end{tabular}

\section{III.-Azotemic Anaemia}

Fernand Widal a long time ago included pallor of the skin and membranes among premonitory signs of azotemia and, collaborating in 1907 with Pierre Abrami and Marcel Brulé, presented 
the first case clearly demonstrating the action of nitrogenous wastes in diminishing the red cells. This case deals with a form of grave aplastic anaemia presenting certain special characters, consisting of the presence of granular red cells without cellular fragility and features not permitting the condition to be grouped unreservedly as aplasia, including intense leucocytosis (of 31,000 ), with femoral bone marrow red throughout its extent and showing totally renewed activity. The case presented nephritis, azotemia, no oedema, marked miosis and high amblyopia, the vision being fogged.

This case served to define the pathogenesis of the pernicious anaemia accompanying nephritis as noted by Grawitz and Ewing, Marcel Labbé, Lortat-Jacob and Salomon. Pasteur-Vallery-Radot has stressed this question and Aubertin and Yacoel have studied it systematically. Anaemic conditions are sometimes associated with a haemorrhagic syndrome, consisting of intestinal or gingival haemorrhages, epistaxis or purpura, and well defined by the studies made by F. Widal and his followers, P. E. Weil and O. Claude, Ch. Achard and Saint-Girons, P. Carnet, F. Rathery and Dumont.

\section{The Characters of this Form of Anaemia are summarized below}

a. Diminution, sometimes considerable, of the number of the red cells, the count showing 950,000, according to Widal, Abrami and Brulé. Ch. Aubertin and Yacoel usually find the red-cell count below 3 million and falling to 900,000 in cases of azotemia, while remaining above 3 million or reaching $4,500,000$ in the absence of azotemia. In 1922, Barach found the average red-cell count 2,738,000 in cases of azotemia. Anisocytosis, poikilocytosis and polychromatophilia occur generally in azotemia and nucleated red cells may exist in proportions of 2 per cent. to 5 per cent. Cellular resistance is not modified. In some cases the globular value is increased, but the total haemoglobin is, naturally, diminished.

b. Leucocytosis may be high, reaching 50,000 (Widal, Abrami and Brulé), with neutrophilic polynucleosis but without myelocytes.

c. Blood coagulation is usually normal or slightly retarded. Plasmatic coagulation occurs frequently and Widal, Abrami and Brulé have observed irretractility of the clot accompanied by a decline in the blood plates, or haematoblasts, which may fall to 40,000 per cubic millimetre.

$d$. With respect to frequency, we may remark that, in ophthalmology, complete details concerning the cases subjected to special ophthalmological examination are not supplied as often as they 
should be. However, seven personal cases of retinitis and azotemic anaemia are significant. The following features serve to verify the statistics of Brown and Roth, who have observed anaemia in 90 per cent. of the cases of nephritis and have stressed, in this connection, the factor of creatininaemia, which exists of 94 per cent. of the cases of nephritic anaemia. In the seven cases mentioned, azotemia was, respectively, of $1.10,1 \cdot 20,1.75,1.80,1.85$, 2.05 and 2.95 grams. Anaemia and leukocytosis coexisted, as follows : red cells, $3,500,000$; white cells, 16,600 ; reds, $3,200,000$; whites, $1,710,000$; reds, $2,800,000$; whites, 20,000 ; reds, $2,800,000$; whites, 25,800 ; reds, $3,000,000$; whites, 18,600 ; reds, 2,250,000 ; whites, 26,200; and reds, 1,150,000; whites, 26,300;

Summarizing, retinal lesion has been observed in 52 per cent. of the cases of azotemic nephritis (Victor Morax and André Weill), while anaemia exists in 90 per cent. of such cases (Brown and Roth). Neither of the two conditions can be separated from azotemia and, in this condition, the lesion constituted by anaemic retinitis appears, as always, an index of the gravity of the case.

\section{Conclusions}

There seems to be no question that close relations exist between azotemia and the anaemia accompanying nephritis. This form of anaemia has its own characters and its course is progressive and parallel with the degree in which nitrogenous wastes are retained. Just as pale, pulverulent, stellate and purpuric infiltration of the retina may sometimes be an early sign of pernicious anaemia or myeloid leukaemia, this same form of retinal infiltration may show the coexistence of anaemia and azotemia; and such retinal infiltration may show the malignity of these types of anaemia before the clinical and haematological signs are fully evident.

The difficulties encountered in interpreting ophthalmoscopic appearances are due to the structure of the retina. The latter is a differentiated tissue and consists of a plane in which the retinal cells and their fibres and connections are spread out and interlaced, thus forming a fabric which is delicate but firm, which necessitates identical distribution of any exudative, fibrinous or haemorrhagic deposit which may be imposed upon it. Duke-Elder has very usefully stressed this morphological consequence of the retinal structure. This consequence develops the fact that, in the absence of the aetiological factors which determine the pathological characters, the latter have no exact significance whatever. Their images are closely alike and, as shown in ophthalmological atlases, represent retinal lesions of widely differing origins which may occur in diabetes, leukaemia, nephritis and even following injuries or zny condition producing local haemorrhage. 
In view of these facts, may statistics which have established the gravity of this aspect of the ocular fundus in the presence of chronic nephritis be opposed by cases in which morphologically identical retinal lesions are not accompanied by signs of renal insufficiency, with which they have been commonly considered to be associated? It is doubtless difficult to distinguish between the various forms of retinitis by ophthalmoscopy alone. Aetiological diagnosis of retinitis is not ophthalmoscopic diagnosis. Clinical determination of these retinal lesions of differing pathogenesis, which are observed in cases of chronic nephritis either alone, associated or in succession, may be made by referring to the accompanying evolutive and aetiological conditions, whose importance in this connection is sufficient to merit special emphasis.

These data are not without clinical interest. In the course of certain acute or subacute forms of nephritis, the pale, pulverulent, stellate and purpuric infiltration of azotemic anaemia shows, early and at the outset, the malignant character of the existing nephritis. Exudative, pale, pulverulent and purpuric infiltration of the retina is but one of the lesions usually accompanying any grave form of anaemia, azotemic anaemia being no exception to this particular rule.

In certain forms of chronic nephritis accompanied by permanent hypertension, it is sometimes difficult to distinguish between lesions revealing the presence of azotemic anaemia and old macrophagic lesions of purely vascular character. In albuminuria, the retina, like a painter's palette, appears as if charged with various mixtures, in which the fundamental elements, the many combinations and the identical characters are distinguishable by means of ophthalmoscopy. Detection and identification of the primary lesions of pale, pulverulent, stellate and purpuric infiltration show the onset of the notably grave period of the azotemic syndrome.

Methodical discrimination of this kind permits an understanding of certain evolutive conditions, considered paradoxical, occur ring in the hypertensive albuminuric retinitis accompanying pregnancy and has also a bearing on the therapeutic problem incident to the gravidic type of pernicious anaemia ${ }^{1}$ which does not present hypertension and in which the punctate and purpuric aspect of the retina is a usual character.

Together with determination of the blood urea, the haematological examination, including the red cell, white cell and platelet counts, the differential leukocyte count, search for abnormal cellforms and examination of the type of coagulation present, supplies

1. Cf. Ch. Aubertin, Presse Médicale, January 5, 1924. Brindeau and TheOdORIDES, anaemia during pregnancy, Viget, Paris, 1934. PIGEAUD, Rochet, Boulez and Leger, Bull. Soc. d'Obst. et de Gynéc., T. XXV, p. 486, 1937. RABOT, Bull. Soc. d'Obst. et de Gynéc., T. XXVI, p. 767, 1937. GAVAUDAN and P. Dor, Bull. Soc. d'Obst. et de Gynéc., T. XXVIII, p. 558, 1938. 
information concerning the nature of lesions whose aetiological interpretation may be doubtful.

\section{BIBLIOGRAPHICAL REFERENCES ON THE MALIGNANT ANAEMIA OF AZOTOMIA}

MARCel, LABBÉ and Lortat-Jacob.-Progressive pernicious anaemia. Chronic neuritis. Goitre. Bull. de la Soc. Anatomique, p. 553, 1903.

MARCel LABbÉ and Salomon.-Pernicious anaemia and chronic nephritis. Bull. et Mém. de la Soc. Méd. des Hôp., p. 83, 1904.

F. WIDAL, P. ABRAMI and M. BRULÉ. Grave fatal anaemia in a case of azotemic nephritis. Bull. et Mém. de la Soc. Méd. des Hôp., p. 1127, December 13, 1907.

P. E. WEIL and O. CLAUDE.-Haemorrhages and disturbances in coagulation in nephritis. Bull. et Mém. de la Soc. Méd. des. Hôp., p. 319, 1907.

MarCel LABbe and Ed. Jéltrain.-Pernicious anaemia and renal lesions. Arch. des Mal. du Coeur., p. 366, 1908.

OUtzekowsKi.-Anaemia in azotomic Bright's disease. Thesis, Paris, 1912-13.

P. Carnot, F. Rathory and Dumont.-A uraemic haemorrhage syndrome. Bull. et Mém. de la Soc. Méd. des Hốp., T. II, p. 64, 1912.

$C_{H}$. AChaRd and SaINT-Girons.-Haemophilia in a case of syphilis complicated with chronic nephritis. Bull. et Mém. de la Soc. Méd. des Hôp., T. I, p. $473,1912$.

Ch. Aubertin and Yacool.-Grave anaemia in azotemic nephritis. Presse Médicale, No. 47, p. 461, 1920, and Soc. Médicale des Hôp., June 13, 1924.

MERKLEN and Minvieille.-Pernicious anaemia and azotemic nephritis. Soc. Méd. des Hôp., p. 1275, 1922.

Brown and Roth.-The anaemia of chronic nephritis. Arch. of Internat. Med., December 15, 1922.

Diena.-Anaemic forms of chronic nephritis. Minerva Medica, 1923.

Ch. Aubertin.-Anaemia and renal insufficiency. Nouveau Traité de Médecine. Fasc. IX, pp. 152-155, Masson and Co., publishers, Paris, 1927.

Gravitz and Ewing.-Cited by F. Widal, A. Lemierre and Pasteur-Vallery-Radot. Noveau Traite de Médecine, Fasc. XVIII, p. 212, Masson and Co., publishers, Paris, 1929.

\section{ANNOTATIONS}

\section{Ocular Complications in Hyperemesis Gravidarum}

An exceedingly important paper on what is something of a by way in ophthalmology, namely the ocular complications of persistent vomiting of pregnancy, has been recently contributed by Professor A. J. Ballantyne to the Journal of Obstetrics and Gynaecology of the British Empire, Vol. 48, No. 2, p. 205.

We think that most ophthalmic surgeons will agree with the author when he says that, although retinitis of pregnancy has long been recognized, the ocular disturbances which may accompany pernicious vomiting in the earlier months are much less widely 